
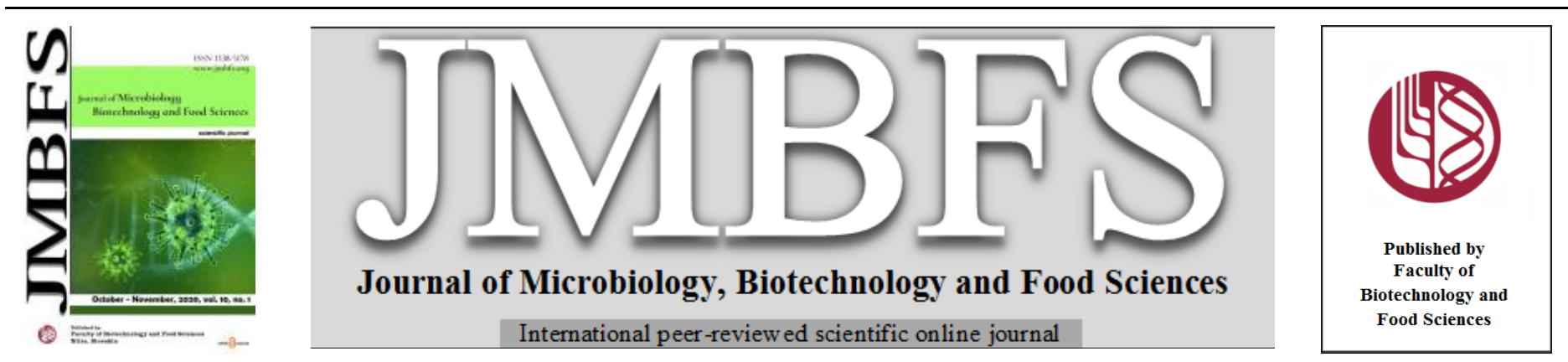

\title{
CADAVERINE: A POTENT MODULATOR OF PLANTS AGAINST ABIOTIC STRESSES
}

\author{
Charu Rajpal ${ }^{1}$, Pushpa C. Tomar*1 \\ Address(es): \\ ${ }^{1}$ Manav Rachna International Institute of Research and Studies, Faculty of Engineering and Technology, Department of Biotechnology, Sector-43, Delhi-Surajkund \\ Road, Faridabad-121004, Haryana., INDIA.
}

*Corresponding author: pushpa.fet@mriu.edu.in

doi: 10.15414/jmbfs.2020.10.2.205-210

\section{ARTICLE INFO}

Received 23. 12. 2019

Revised 5. 6. 2020

Accepted 12. 6. 2020

Published 1. 10. 2020

Review OPEN $\partial_{\text {ACCESS }}$

\begin{abstract}
Environmental stresses are a major threat for agricultural productivity. But certain biotic and abiotic stresses like salinity and heavy metals, especially cadmium and lead are the main cause of soil degradation and inhibit germination, speed of germination, dry mass accumulation, photosynthetic pigments due to perturbed physiochemical processes resulting decline in growth and related metabolites. Salinity possesses a negative impact on plant growth as it causes plant intoxication and osmotic stress which interferes with the crop development. While heavy metals inhibit nitrate reductase activity and decrease organic nitrogen and protein contents. Their higher concentrations can severely distress the growth of plant and biomass yield. The dynamic approaches of PA's are demonstrated in all the disciplines like plant sciences, human health and microbiology. Despite their important contributions in research, still some areas remain least explored like the action of polyamines in plant stress physiology and its future practical applications. Cadaverine (Cad), a structurally different diamine which has an independent biosynthetic pathway also comes under the family of polyamines. It improves crop salt tolerance; improvise heavy metal stress, acts as a plant growth regulator that further activates antioxidant defense system and it intensely upholds the stressed plant growth through preserving the metabolites.
\end{abstract}

\section{INTRODUCTION}

Polyamines being small positively charged metabolites that are indulged in several physiological procedures like fruit growth and ripening, floral initiation, embryogenesis, organogenesis, pollen tube growth, leaf senescence and mitigating abiotic and biotic stresses (Tiburcio et al., 2014). Functionally, these molecules exhibit their function in varied range of biological procedures. Since last few years, molecular genetic studies have contributed immensely in understanding the transformed activity of enzymes in the synthesis of PA and their probable biological functions in plants. Furthermost of the former research have concerned 3 biogenic amines: putrescine (Put), spermidine (Spd) and Spermine (Spm) and their derivatives (Liu et al., 2015). Over-expression of genes indulged in biosynthesis of polyamines results in building up of PA and therefore, more stress tolerance. These polyamines are biosynthesized by arginine or ornithine decarboxylation by (ADC) or (ODC) respectively (Walter, 2003) Cadaverine that is a structurally different diamine following an independent pathway for its biosynthesis with respect to Put, also comes under the family of polyamines considered as a growth regulator and follows the same mode of action. It also tends to accumulate in higher plants under several biotic and abiotic stresses without its elaborated role in stress alleviation. It is a five carbon chain diamine and structural analog to putrescine is not synthesized in Arabidopsis (Liu et al., 2014). It is synthesized from the amino acid arginine. Agmatine is formed from ariginine and this reaction is catalysed by arginine decarboxylase (ADC), followed by its transformation into N-carbamoyl putrescine which ultimately gets converted into Cad using agmatine imino hydroxylase (AIH). Alternatively, Cad is also synthesized by a set of methionine synthesis through aspartate pathway. On the other hand, ornithine decarboxylase (ODC) uses lysine as a varied substrate for Cad synthesis. Alkaloids being one of the important metabolites, of which lysine-derived alkaloids demonstrates large variety of pharmacological properties like these are anti- cancerous, antiinflammatory, anti- Alzheimer disease, anti- arrhythmic and hypocholesterolemic effects. These alkaloids are found in many species of flowering plants and an essential amino acid produced in the plastids of terrestrial plants. These are distributed into four major groups named: - quinolizidine, lycopodium, piperidine and indolizidine. Lysine decarboxylase is first usual step in the synthesis of cadaverine which is then oxidized by copper amine oxidase and cyclized to delta 1- piperidine schiff's base spontaneously (Bunsupa et al., 2017). Proteomic analysis of medicinal plants demonstrated that alkaloids synthesis related proteins might play a crucial role in secondary metabolite production. These proteins are codeinone reductase, 12-oxophytodienoate reductase, tryptophan synthase \& strictosidine synthase (Keyvan Aghaei \& Setsuko Komatsu, 2013).

A few recent studies have emphasized the effect of shoot tissue responses towards the excess salt concentration, by minimizing the accumulation of toxic ions in leaf causing hampered growth and productivity of plant (Julkowska $\boldsymbol{e t}$ al., 2014). Excess accumulation of salt ions existing in the soil apply osmotic pressure that reduces the water uptake by the roots of the plants leading to excessive accumulation of reactive oxygen species (ROS) (Jiang $\boldsymbol{e t}$ al., 2016), and causes root membrane disruption (Gupta \& Huang 2014). Inflow of increased concentration of $\mathrm{Na}^{+}$to the root cells in general causes the outflow of cytosolic $\mathrm{K}^{+}$thus creating an imbalance of ion concentration leading to metabolic disorders (Witzel et al., 2009). Li et al. (2014) and Saha et al. (2015) stated that PA-PA interact with ion channels and contribute to ion homeostasis (Pottosin $\boldsymbol{e}$ al., 2014). Regulation of ROS homeostasis throughout salt stress is done by PAs by inducing the activation of antioxidant defense system. In the signal transduction pathway, stress signals are observed by sensors that are mostly placed at the cytomembrane, results in the unharness or activating several secondary messengers such as calcium, ROS and inositol phosphates that convey the stress signals and stimulates downstream elements, like protein kinases and phosphatases (Nakashima et al., 2009; Danquah et al., 2014; Liu et al., 2014a; Ma et al., 2015).

There is a tendency to anticipate numerous existing challenges in agronomy to deal with environment modifications and uphold biological procedures and quality of fruits and vegetables that will be advanced by considering the polyamine pathway. As demonstrated by Tomar et al. (2013), lysine decarboxylase catalyses lysine catabolism, which is developmentally regulated. Activation of multiple pathways due to binding of PA has resulted in increased salinity and draught tolerance in Burmund grass (Cynodon dactylon) (Shi et al., 2013). The Cad diverse presence in plant parts/products recommends it as a prospective candidate for taxonomic marker as well as for marketable manipulation along with plant growth and development.

Compared with other PAs, studies on role of Cad have been fragmented. Shalaby et al. (2000) discovered that concentration of Cad increased during germination in broad bean, chick pea and lupine. Garcia-Garcia et al. (2000) observed presence of small quantities of cadaverine in table olives after three months of 
brining. Shen \& Galston (1985) demonstrated Cad in corn coleoptiles, pea and tomato and in Datura (Carrizo et al., 2001). They have demonstrated the dependence of cadaverine titres on plant age and concluded that Cad declines progressively with age. Han et al. (2000) found elevated quantity of Cad in immature citrus species seeds. Piqueras et al. (2002) found high level of $\mathrm{Cad}$ conjugation under hyperhydric plants of carnation.

Fecker and his group (1993) observed the enhanced manufacturing of cadaverine in hairy root cultures of Nicotiana tobacum. Carrizo et al. (2001) found the existence of cadaverine in hairy roots of Brugmansia candida. Cadaverine application may induce rooting in the existence of ectomycorrhizal fungi in scot pine (Niemi et al., 2002). It may affect nodule metabolism by changing bacteriods (Vassileva \& Ignatov 2002). Recently, Goyal et al. (2016) found that pathogenesis-related protein $1 \mathrm{~b} 1$ (PR1b1) is a chief tomato fruit protein receptive to chilling temperature and up regulated in high polyamine transgenic genotypes. Nambeesan et al. (2012) suggested that polyamine mediated vulnerability to Botrytis cinerea in Tomato is interrelated to intrusion with the roles of ethylene in its defence. The ripening-related metabolic variations are both ethylene independent and dependent, and the fruit metabolome is controlled by multiple regulators, comprising ethylene and $\mathrm{PA}$.

\section{BIOSYNTHESIS}

Polyamines are phytohormones that are aliphatic and ubiquitous in nature, like the diamine Put $\left[\mathrm{NH}_{2}\left(\mathrm{CH}_{2}\right)_{4} \mathrm{NH}_{2}\right]$ that acts as a precursor for the triamine Spd

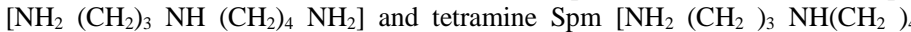
$\left.\mathrm{NH}\left(\mathrm{CH}_{2}\right)_{3} \mathrm{NH}_{2}\right]$. All these polyamines differ from each other in the number of positive charges present on them physiologically. The biosynthesis of Put adopts ADC (Adenosine decarboxylase) via agmatine or ODC (Ornithine decarboxylase) pathway. Agmatine is formed from arginine and this reaction is catalysed by ADC, followed by its transformation into N-Carbamoyl putrescine which ultimately gets converted into Cadaverine using agmatine imino hydroxylase (AIH). Spd serves as a substrate for the biosynthesis of Spm.

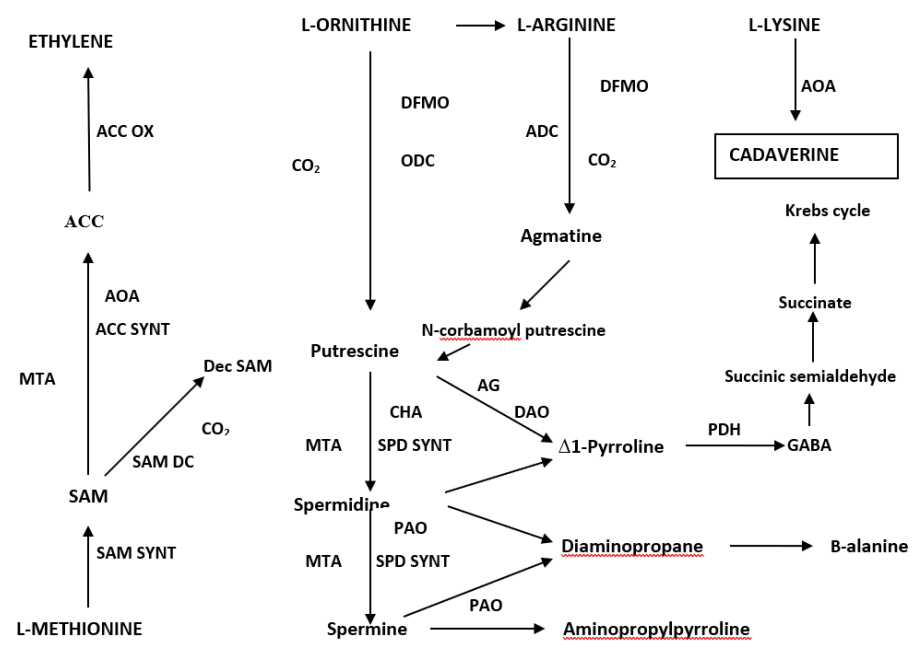

Figure 1 Schematic outlines of the pathways of polyamine synthesis and catabolism

Enzymes: ADC, arginine decarboxylase methionine

ODC, ornithine decarboxylase

LDC, lysine decarboxylase

1 -

SPD SYNT, spermidine synthase

SPM SYNT, spermine synthase

DAO, diamine oxidase

PAO, polyamine oxidase

$\mathrm{PDH}$, pyrroline dehydrogenase

difluoromethylarginine

SAM SYNT, SAM synthase

SAM DC, SAM decarboxylase

ACC SYNT, ACC synthase

ACC OX, ACC oxidase

sulphate

Diamine oxidases (DAO) are involved in the conversion of diamine Put into $\Delta^{\prime}$ pyroline and releases $\mathrm{H}_{2} \mathrm{O}_{2}$ and ammonia as the secondary by-products. These DAO's are found in the cell wall of the plant cells while $\mathrm{H}_{2} \mathrm{O}_{2}$ released is responsible for the catabolism of Put that facilitates the lignification and cross- linking under multiple stress conditions. Catabolization of $\Delta^{\prime}$-pyroline into $\lambda$ aminobutyric acid (GABA) as shown in Fig. 1 leads to its conversion into succinic acid that is further a Kreb's cycle component (Eller et al., 2006) Spermidine, Cadaverine and Putrescine are the major essential precursors for the biosynthesis of alkaloids in a few plant species. Polyamines are involved in plant growth in several aspects as in an associated form with proteins and cinnamic acids. Now several genes indulged in such associations have been identified rapidly (Takahashi and Tong, 2015).

\section{QUANTIFICATION}

As polyamine contribute to basic cellular function their quantification is essential in diverse biological origin to understand their specific function in disease relevant condition. This is performed through high throughput solid phase extraction coupled with LC (liquid chromatography). Polyamines like Putrescine, Spermidine, Spermine are simultaneously quantified in various biological samples. The use of two solid-phase extraction columns joined with liquid chromatography-mass spectrophotometry is novelty of the work. This minimizes the sample pre-treatment to a single derivation stage which makes the method highly suitable for high throughput screening and routine clinical analysis. This method is validated with serum samples completely. Ranges vary dynamically from 0.03 to $15 \mu \mathrm{g} / \mathrm{ml}$ for ornithine and 1 to $500 \mathrm{ng} / \mathrm{ml}$ for other polyamines covering all the physiological concentrations. LloQ (Lower limits of quantification) vary between 0.1 and $5 \mathrm{ng} / \mathrm{ml}$ (Magnes et al., 2014)

An escalation in the amount of putrescine was detected when tomato plants were grown with $\mathrm{NH}_{4}{ }^{+}$as the only $\mathrm{N}$ source (Fernandez-Crespo et al., 2015). DFMA and DFMO being the inhibitors of synthesis of putrescine were used as irretrievable inhibitors of enzymes like ODC and ADC to estimate the importance and accumulation of putrescine (Fallon and Phillips, 1988) and this was done to decrease the accumulation of cellular putrescine which was induced by $\mathrm{NH}_{4}{ }^{+}$nutrition. Similarly, when an inhibitor solution of $2 \mathrm{mM}$ DFMA and $5 \mathrm{mM}$ DFMO was applied for a week before collecting the samples, the content of putrescine was observed to be condensed by $35.3 \%$ in the plants when growth with $\mathrm{NH}_{4}{ }^{+}$(Fernandez-Crespo et al., 2015).

\section{EFFECT OF ABIOTIC STRESSES ON PLANTS}

Abiotic stresses like salinity and heavy metal accumulation possess a negative impact in plant growth in irrigated and non-irrigated areas in various worlds' barren regions and are one of the main concerns for agriculture (Nasr et al. 2012; Meloni et al., 2008; Ríos-Gómez et al., 2010; Velarde et al., 2003). This causes plant intoxication and osmotic stress which interferes with the crop development (Porta et al., 1999). There are various microorganisms which act as an osmo-protectant to seedlings of tomato when grown in saline cultures. For example, to enhance the tomato osmo tolerance seeds were associated with Azospirullum brasilense $C d$ which transforms bacteria with a plasmid concealing a trehalose biosynthesis gene fusion or Chlorella vulgaris. These two showed a positive response on tomato. This increased the salt tolerance of tomato in hydroponic culture by microbial association.

The primary effects observed during soil salinity are much related as exhibited by plants when exposed to drought. Photosynthetic metabolism is inhibited when stomatal conductance is reduced by reduction in potential of leaf water (Zribi $\boldsymbol{e t}$ al., 2009). The biofertilizers mobilize and preserve nutrients in the soil. For example: - Azospirullum is the plant growth promoting bacteria which has the capability to enhance plant growth development and yield of several agronomic crops (Givandan and Bally, 1991; Strzelczyk et al., 1994).

Nacl sensitivity was explained by threating plant roots with cadaverine. Plants were grown with or without $2 \mathrm{mM}$ cadaverine and then subjected to DAB staining. The root growth with $2 \mathrm{mM}$ cadaverine treatment was severely inhibited The root tip portion were heavily stained exhibiting the manufacturing of higher levels of $\mathrm{H}_{2} \mathrm{O}_{2}$ (Liu et al., 2014)

Likewise NO effects the salt induced variations in free amino acid levels of maize. Subsequently, lysine and argentine are responsible for synthesis of polyamines, it is expected that nitric oxide also influences their concentration. NO donor increases the cadaverine levels and gets decreased by an inhibitor of NO synthesize in salt stressed maize. This indicates that cadaverine levels and NO concentration is responsible in amending the response to solve stress in maize (Simon-Sarkadi et al., 2014).

Due to environmental unfavourable conditions salinity is prevalent in the world Growth and crop production severely gets effected due to salt stress while there are certain cultivars of crops that demonstrate substantial tolerance against the effects of salinity. Among these salt stress proteomic responses plays an important role to manage with it and have become the core centre of interest. Various physiological responses are responsible for protein upsurge and reduction even before changes in the physiology of the plants take place. So, proteomic approach marks a bridge in the path of interfering how crops response to salt stress. Various proteins that are responsive to salt have been discovered in major crops that can withstand against salt stress. For example- heat shock proteins, pathogen related proteins, ODC, ascorbate peroxidase, osmotin, protein kinase and other transcription factor (Keyvan Aghaei \& Setsuko Kematsu, 
2013). In contrast, when two cultivars of tomato L. Esculentum Mill (Roma and Rio Grande) were opened to pre-treated cheese whey waste water (CWW) used at different salinity concentrations $1.75,2.22,3.22,5.02$ and $10.02 \mathrm{dsM}(-1)$ and compared with fresh water $(1.44 \mathrm{dsM}(-1))$. No prominent effects on the dry biomass and fresh weight of the parts of the plant like leaves stem and roots were observed (Prazeres et al., 2013). For the study of defined stimuli like hormone or abiotic stress treatments profiling of transcriptomics should be specifically mentioned (Kilian et al., 2012) and so the microarray analysis of Arabidopsis thaliana genome has delivered a useful technique to find the effects of various gene expressions (Redman et al., 2004; Zeller et al., 2009). For example- during a survey around 2400 Arabidopsis genes out of 8100 genes have shown the common expression to salt, osmotic and cold- stress treatment (Kreps et al., 2002).

\section{ABIOTIC STRESS MITIGATION}

The study of polyamine response on growth and developmental aspect of plant is now being dealt by a number of scientists. Several groups have worked upon different aspects of PA. Put, Spd and Spm are the three most verdant polyamines which show abundantly enhanced measure of abiotic stresses (Yang et al., 2007). It has been observed in the majority cases that just one variety of the 3 polyamines show an apparent enhancement. For an instance, when Liu et al.
(2006) treated callus of apple with salt, Put. levels amplify, whereas other PA like Spd and Spm experience insignificant changes. In a different study, it was conveyed that 18 different varieties of rice unveiled prominent deviations in Spm levels when they experience drought stress for a long period (Do et al., 2014). Such reports suggest that accumulation of polyamines is affected by variety of aspects like species of plants, their stress tolerance capacity, stress varieties and other environmental surroundings, and therefore the physiology of the inspected tissue/organs. This further specifies that the reason for getting differing and contradictory results is the presence of extensive PA dynamics under abiotic stress. The extent of PA pool may be related to the stress tolerance capacity, more emphasizing the importance of PA's in providing defense against stresses (Hatmi et al., 2015). Compelling proof specifies the involvement of PA in abiotic and biotic stress responses in plants. Certainly, genetic engineering of polyamine levels in plants has enhanced biotic and abiotic stress resistance in exemplary plants and crops effectively. There is a tendency to anticipate numerous existing challenges in agronomy to deal with environment modifications and uphold biological procedures and quality of fruits and vegetables that will be advanced by considering the polyamine pathway. As demonstrated by Tomar et al. (2013), lysine decarboxylase catalyzes lysine catabolism, which is developmentally regulated.

Table 1 Depicting multiple abiotic stress mitigation by different polyamines

\begin{tabular}{|c|c|c|c|c|}
\hline Plant/Crop name & $\begin{array}{c}\text { Stress/Activity } \\
\text { involved }\end{array}$ & Polyamine(s) used & Metabolic activity effected & References \\
\hline Apple callus & Salt & Putrescine & $\begin{array}{c}\text { Importance of arginine } \\
\text { decarboxylase pathway in stress } \\
\text { response. }\end{array}$ & Liu et al. (2006) \\
\hline Rice & Salt, Drought & Spermine & $\begin{array}{l}\text { Changes in free PA levels, } \\
\text { expression of polyamine } \\
\text { biosynthesis genes. }\end{array}$ & Do et al. (2014) \\
\hline Burmund Grass & $\begin{array}{l}\text { Salinity and } \\
\text { Drought }\end{array}$ & Spermidine & $\begin{array}{c}\text { Comparative proteomic and } \\
\text { physiological analyses revealed the } \\
\text { protective effect of PA. }\end{array}$ & Shi et al. (2013) \\
\hline $\begin{array}{l}\text { Legumes (Broad } \\
\text { Bean, Chick pea and } \\
\text { Lupine) }\end{array}$ & Temperature & Cadaverine & Changes in biogenic amines. & Shalaby et al. (2000) \\
\hline Table Olives & Salt & Cadaverine & $\begin{array}{l}\text { Content of Biogenic amines } \\
\text { determined. }\end{array}$ & Garcia-Garcia et al. (2000) \\
\hline $\begin{array}{l}\text { Corn coleoptiles, Pea, } \\
\text { Tomato }\end{array}$ & Osmotic & Cadaverine & $\begin{array}{l}\text { Correlations between PA ratio and } \\
\text { growth patterns. }\end{array}$ & Shen and Galston (1985) \\
\hline Datura & $\mathrm{Na}_{2} \mathrm{SO}_{4}$ & Cadaverine & Cad declines with age & Carrizo et al. (2001) \\
\hline Citrus species & $\begin{array}{c}\text { Salinity } \\
\text { Expression of }\end{array}$ & Cadaverine & $\begin{array}{c}\text { High amount of endogenous Cad } \\
\text { observed }\end{array}$ & Han et al. (2000) \\
\hline Tobacco & $\begin{array}{l}\text { bacterial lysine } \\
\text { decarboxylase } \\
\text { gene }\end{array}$ & Cadaverine & $\begin{array}{l}\text { Increased production of Cad } \\
\text { expressing a bacterial LDC gene }\end{array}$ & Fecker et al. (1993) \\
\hline Datura & $\mathrm{Na}_{2} \mathrm{SO}_{4}$ & Cadaverine & Occurance of Cad in roots & Carrizo et al. (2001) \\
\hline Scot pine & $\begin{array}{l}\text { Nitrogen- } \\
\text { fixation }\end{array}$ & Cadaverine & $\begin{array}{l}\text { Nodule metabolism effected by } \\
\text { changing bacteroids }\end{array}$ & $\begin{array}{l}\text { Vassileva and Ignatov } \\
\qquad(\mathbf{2 0 0 2})\end{array}$ \\
\hline Tomato & $\begin{array}{c}\text { High } \\
\text { Temperature }\end{array}$ & $\begin{array}{l}\text { Spermidine/ } \\
\text { Spermine }\end{array}$ & $\begin{array}{l}\text { PA accumulation in transgenic } \\
\text { tomato enhances the stress } \\
\text { tolerance }\end{array}$ & Cheng et al. (2009) \\
\hline Tomato & $\begin{array}{c}\text { High } \\
\text { Temperature }\end{array}$ & Spermidine & Transcriptome responses effected & Cheng et al. (2012) \\
\hline Maize & Salinity & Spermidine & $\begin{array}{l}\text { Chloroplast antioxidant system and } \\
\text { Chlorophyll metabolism regulated }\end{array}$ & Jianming et al. (2015) \\
\hline Tomato & Temperature & Cadaverine & $\begin{array}{l}\text { Up regulation in high polyamine } \\
\text { transgenic genotypes } \\
\text { Protein: Pathogenesis related } \\
\text { protein 1b1 (PR1b1) }\end{array}$ & Goyal et al. (2016) \\
\hline
\end{tabular}


Activation of multiple pathways due to binding of PA has resulted in increased salinity and draught tolerance in Burmund grass (Cynodon dactylon) (Shi et al., 2013). The Cad diverse presence in plant parts/products recommends it as a prospective candidate for taxonomic marker as well as for commercial manipulation along with plant growth and development.

Compared with other PAs, studies on role of Cad have been fragmented. Shalaby et al. (2000) discovered that concentration of Cad increased during germination in broad bean, chick pea and lupine. Garcia-Garcia et al. (2000) observed presence of small quantities of cadaverine in table olives after three months of brining. Shen \& Galston (1985) demonstrated Cad in corn coleoptiles, pea and tomato and in Datura (Carrizo et al., 2001). They have demonstrated the dependence of cadaverine titres on plant age and concluded that Cad declines progressively with age. Han et al. (2000) found elevated amount of Cad in immature seeds of citrus species. Piqueras et al. (2002) found high level of $\mathrm{Cad}$ conjugation under hyperhydric plants of carnation.

Fecker and his group (1993) observed the enhanced production of cadaverine in hairy root cultures of Nicotiana tobacum. Carrizo et al. (2001) found the occurrence of cadaverine in hairy roots of Brugmansia candida. Cadaverine application may induce rooting in the presence of ectomycorrhizal fungi in scot pine (Niemi et al., 2002). It may affect nodule metabolism by changing bacteriods (Vassileva \& Ignatov 2002). Under heat shock, cadaverine level increased many fold compared with others in ice plants (Kuznetsov et al. 2002).

Recently, Goyal et al. (2016) found that pathogenesis-related protein $1 \mathrm{~b} 1$ (PR1b1) is a chief tomato fruit protein receptive to chilling temperature and up regulated in high polyamine transgenic genotypes. Nambeesan et al. (2012) suggested that PA-mediated vulnerability to Botrytis cinerea in Tomato is interrelated to intrusion with the functions of ethylene in its defence. The ripening-related metabolic variations are both ethylene dependent and independent, and the fruit metabolome is under the control of multiple regulators, comprising ethylene and PA.

Cheng et al. (2009) found that accumulation of PA in transgenic tomato improves the high temperature stress tolerance. Hence it postulates that PA shows a significant part in plant response to abiotic stress. Hichri et al. (2014) validated that the zinc finger superfamily comprises of transcription factors that standardize numerous characteristics of plant development and revealed to regulate abiotic stress tolerance recently. As described by Cheng et al. (2012); Spermidine distresses the transcriptome responses to high temperature stress in ripening tomato fruit. Many studies suggested that, transgenic gene lines or exogenous application showed a progressive role of polyamines in environmental stress tolerance (Kamiab et al., 2014). Comparative proteomic analysis could help in considering the mechanism of environmental stresses tolerance in the presence of PAs (Witzel et al., 2009). Jianming $\boldsymbol{e t}$ al. (2015) reported enhanced tolerance to salinity-alkalinity stress in presence of exogenous spermidine by amending chlorophyll metabolism and chloroplast antioxidant system. By eradicating reactive oxygen and nitrogen species in citrus leaves, which are bare to salinity stress proteins, tyrosine nitration and carbonylation can become effectively low (Tanou et al., 2014). Voltage dependent $\mathrm{K}^{+}$channels regulate the inhibition of the opening and closure of stomata (Liu et al., 2000) or $\mathrm{H}_{2} \mathrm{O}_{2}$ signals (Konstantinos et al., 2010) through PAs which results in transpiration restriction and reduction in water loss (Yuan 2016). As stated by Fernandez-Crespo et al. (2015) that $\mathrm{NH}^{4+}$ nutrition provides slight toxicity by increasing $\mathrm{H}_{2} \mathrm{O}_{2}$ accumulation that functions as a signal stimulating systemic attained acclimatization. Moreover, this study discovered the cross-talk between abiotic stress acclimatization $\left(\mathrm{NH}^{4+}\right.$ nutrition) and resistance to consequent Pst infection.

\section{CONCLUSION AND FUTURE ASPECTS}

Many environmental abiotic stresses like global warming are severely affecting the productivity of the plants across the globe and this study is about identifying new potentials in agricultural biotechnology considering the current scenario of soil infertility in several states of India. This is extremely serious because India supports $18 \%$ of world's human population and $15 \%$ of the world's livestock population but has only $2.5 \%$ of world's land area. Biotic and abiotic stresses are the main cause of soil degradation. Salinity and heavy metal pollution is a great threat to soil fertility. Heavy metals enter to the soil-plant environment through anthropogenic sources. These substances adversely affect the productivity of soil, plants, animals and the entire environment if exceeds the certain limits. Among all the heavy metals, cadmium is highly toxic for both plants and animals. Compounds of cadmium are more soluble than other heavy metals rendering it more available for plant absorption where these could accumulate in edible plant part while lead is mostly present in top layer of soil due to deposition from air containing smoke from vehicles. Though, when Cad was added to cadmium stressed plants, no change was observed in peptide expression over the $\mathrm{Cad}$ treated one, while none of metal suppressed peptide was expressed due to Cad. Alike response was observed in $\mathrm{Pb}$ exposed plants (Tomar et al., 2017).

Similarly certain processes like weathering and deposition of oceanic salt carried in wind and rain are the major natural factors responsible for soil salinity. While human activities like land clearing and irrigation are other factors for salinization that change the hydrologic balance of the soil. This results in accumulation of the dissolved salts in soil water to an extent that inhibits plant growth. Polyamines like Cadaverine (Cad) are aliphatic polycations that tend to accumulate in higher plants under several biotic and abiotic stresses over-express the genes responsible for stress tolerance. Physiological analysis can be performed to observe the effects of $\mathrm{Cad}$ on biomass accumulation, increment of bio molecules (photosynthetic pigments, total soluble proteins, organic nitrogen) and nitrate reductase activity which is well correlated with growth stress on plants that will provide an insight by comparative proteomic and genomic studies comprehensively along with a better understanding about mechanism of Cad that will improvise the tolerance of multiple stress in several plants.

\section{REFERENCES}

BUNSUPA, S., YAMAZAKI, M., SAITO, K._2017. Lysine-derived Alkaloids: Overview and Update on Biosynthesis and Medicinal Applications with Emphasis on Quinolizidine Alkaloids. Medicinal Chemistry, 17(12), 1002-1012. https://doi.org/10.2174/1389557516666160506151213.

CARRIZO, C. N., PITTA-ALVAREZ, S. I., KOGAN, M. J., GIULIETTI, A. M., TOMARO, M. L. 2001. Occurrence of cadaverine in hairy roots of Brugmansia candida. Phytochemistry, 57(5), 759-763. https://doi.org/10.1016/S00319422(01)00127-3.

CHENG, L., ZOU, Y., DING, S., ZHANG, J., YU, X., CAO, J., LU, G. 2009 Polyamine accumulation in transgenic tomato enhances the tolerance to temperature stress. Journal of Integrative Plant Biology, 51(5), 489-99. doi:10.1111/j.1744-7909.2009.00816.x.

CHENG, L., RONG-RONG, S., FEI-YAN, W., ZHEN, P., FU-LING, K., JIAN, W., JIA-SHU, C., GANG, L. 2012. Spermidine affects the transcriptome responses to high temperature stress in ripening tomato fruit. Journal of Zheijiang University, SCIENCE B. 13(4), 283-297. https://doi.org/10.1631/jzus.B1100060. DANQUAH, A., DE ZELICOURT, A., COLCOMBET, J., HIRT, H. 2014. The role of ABA and MAPK signaling pathways in plant abiotic stress responses. $\begin{array}{lll}\text { Biotechnology } & \text { Advances, } & \text { 32(1), }\end{array}$ https://doi.org/10.1016/j.biotechadv.2013.09.006.

DO, P. T., DRECHEL, O., HEYER, A. G., HINCHA, D. K., ZUTHER, E. 2014 Changes in free polyamine levels, expression of polyamine biosynthesis genes and performance of rice cultivars under salt stress: a comparison with responses to drought. Frontiers in Plant Science, 5,182. https://doi.org/10.3389/fpls.2014.00182.

ELLER, M. H., WARNER, A. L., KNAP, H.T. 2006. Genomic organization and expression analyses of putrescine pathway genes in soybean. Plant Physiology and Biochemistry, 44, 49-57. doi:10.1016/j.plaphy.2006.01.006.

FALLON, K. M., PHILLIPS, R. 1988. Polyamines in relation to growth in carrot $\begin{array}{llll}\text { cell cultures. Plant } & \text { Physiology, } & 88(1), & 224-227\end{array}$ https://doi.org/10.1104/pp.88.1.224.

FECKER, L. F., RÜGENHAGEN, C., BERLIN, J. 1993. Increased production of cadaverine and anabasine in hairy root cultures of Nicotiana tabacum expressing a bacterial lysine decarboxylase gene. Plant Molecular Biology, 23(1), 11-21. https://doi.org/10.1007/BF00021415.

FERNANDEZ-CRESPO, E., SCALSCHI, L., LLORENS, E., GARCIAAGUSTIN, P., CAMANES, G. 2015. $\mathrm{NH}_{4}{ }^{+}$protects tomato plants against Pseudomonas syringae by activation of systemic acquired acclimation. Journal of Experimental Botany, 66(21), 6777-6790. https://doi.org/10.1093/jxb/erv382.

GARCIA-GARCIA, P., BRENES-BALBUENA, M., HORNERO-MENDEZ, D. GARCIA-BORREGO, A., GARRIDO- FERNANDEZ, A. 2000. Content of biogenic amines in table olives. Journal of Food Protection, 63(1), 111-116. https://doi.org/10.4315/0362-028X-63.1.111.

GIVANDAN, A., BALLY, R. 1991. Similarities between large plasmids of Azospirillum lipoferum. FEMS Microbiology Letters, 78(2-3), 245-251. http://www.sciencedirect.com/science/article/pii/0378109791901657.

GOYAL, R. K., FATIMA, T., TOPUZ, M., BERNADEC, A., SICHER, R. HANDA, A. K., MATTOO, A. K. 2016. Pathogenesis- Related Protein 1b1 (PR1b1) is a major Tomato fruit protein responsive to chilling temperature and up regulated in high polyamine transgenic genotypes. Frontiers in Plant Science, 901(7), 1-14. DOI: 10.3389/fpls.2016.00901

GUPTA, B., HUANG, B. 2014. Mechanism of salinity tolerance in plants: physiological, biochemical, and molecular characterization. International Journal of Genomics, 6, 727-740. http://dx.doi.org/10.1155/2014/701596.

HAN, K. R., KIM, M. W., KIM, H. Y., RIU, K. Z., LEE, S., OK, Y. 2000. Endogeneous levels of polyamines in citrus and related species: Their role in in vitro organogenesis, somatic embryogenesis and recalcitrance. Plant Biology conference organized by American Society of Plant Biologists in San Diego, 118. HATMI, S., GRUAU, C., TROTEL-AZIZ, P., VILLAUME, S. RABENOELINA, F., BAILLIEUL, F. EULLAFFROY, P., CLÉMENT, C., FERCHICHI, A., AZIZ, A. 2015. Drought stress tolerance in grapevine involves activation of polyamine oxidation contributing to improved immune response and low susceptibility to Botrytis cinerea.. Journal of Experimental Botany, 66, 775787. https://doi.org/10.1093/jxb/eru436.

HICHRI, I., MUHOVSKI, Y., ZIZKOVA, E., DOBREV, P. I., FRANCOZORRILLA, J. M., SOLANO, R., LOPEZ-VIDRIERO, MOTYKA, V., LUTTS S. 2014. The Solanum Lycopersicum Zinc Finger2 cysteine-2/histidine-2 
repressor-like transcription factor regulates development and tolerance to salinity in tomato and Arabidopsis. Plant Physiology, 164(4), 1967-90. https://doi.org/10.1104/pp.113.225920.

JIANG, K., MOE-LANGE, J., HENNET, L., FELDMAN, L. 2016. Salt stress affects the redox status of Arabidopsis root meristems. Frontiers in Plant Science, 7, 8. https://doi.org/10.3389/fpls.2016.00081.

JIANMING, L., LIPAN, H., LI, Z., XIONGBO, P., XIAOHUI, H. 2015. Exogenous spermidine is enhancing tomato tolerance to salinity-alkalinity stress by regulating chloroplast antioxidant system and chlorophyll metabolism. BMC Plant Biology, 15, 303, 1-17. https://doi.org/10.1186/s12870-015-0699-7.

JULKOWSKA, M.M., HOEFSLOOT, H.C.J., SELENA, M., RICHARD, F., GERT-JAN, D.B., HARING, M.A. 2014. Capturing Arabidopsis root architecture dynamics with ROOT-FIT reveals diversity in responses to salinity. Plant physiology, 166, 1387-1402. doi:10.1104/pp.114.248963.

KAMIAB, F., TALAIE, A., KHEZRI, M., JAVANSHAH, A. 2014. Exogenous application of free polyamines enhance salt tolerance of pistachio (Pistacia vera L.) seedlings. Plant Growth Regulation, 72, 257-268 https://doi.org/10.1007/s10725-013-9857-9.

KEYVAN, A., SETSUKO, K. 2013. Crop and medicinal plants proteomics in response to salt stress. Frontiers in Plant Science, 4, 8. DOI 10.3389/fpls.2013.00008.

KILIAN, J., PESCHKE, F., BERENDZEN, K. W., HARTER, K., WANKE, D. 2012. Prerequisites, performance and profits of transcriptional profiling the abiotic stress response. Biochimica et Biophysica Acta, 1819, 166-175 doi:10.1016/j.bbagrm.2011.09.005.

KONSTANTINOS, P. A., TOUMI, I., PANAGIOTIS, M. N., ROUBELAKIS ANGELAKIS, K. A. 2010. ABA-dependent amine oxidases-derived H2O2 affects stomata conductance. Plant Signalling and Behavior, 5, 1153-1156. https://doi.org/10.4161/psb.5.9.12679.

KREPS, J. A., WU, Y., CHANG, H. S., ZHU, T., WANG, X., HARPER, J. F. 2002. Transcriptome changes for Arabidopsis in response to salt, osmotic, and cold stress. Plant Physiology, 130, 2129-2141. DOI: 10.1104/pp.008532.

KUZNETSOV, V. V., RAKITIN, V. Y., SADOMOV, N. G., DAM, D.V. STETSENKO, L. A., SHEVYAKOVA, N. I. 2002. Do polyamines participate in the long-distance translocation of stress signals in plants? Russian Journal of Plant Physiology, 49, 120-130. https://doi.org/10.1023/A:1013776631284.

LI, Z., ZHANG, Y., PENG, D., WANG, X., PENG, Y., HE, X. 2015. Polyamine regulates tolerance to water stress in leaves of white clover associated with antioxidant defense and dehydrin genes via involvement in calcium messenger system and hydrogen peroxide signalling. Frontiers in Physiology, 6, 280. DOI: 10.3389/fphys.2015.00280.

LIU, J. H., NADA, K., HONDA, C., KITASHIBA, H., WEN, X. P., PANG, X M. 2006. Polyamine biosynthesis of apple callus under salt stress: importance of the arginine decarboxylase pathway in stress response. Journal of Experimental Botany, 57, 2589-2599. DOI: 10.1093/jxb/erl018.

LIU, J. H., PENG, T., AND DAI, W. S. 2014a. Critical cis-acting elements and interacting transcription factors: key players associated with abiotic stress responses in plants. Plant Molecular Biology Reporter, 32, 303-317. DOI: $10.1007 / \mathrm{s} 11105-013-$

0667-Z.

LIU, J. H., WANG, W., WU, H., GONG, X., MORIGUCHI, T. 2015. Polyamines function in stress tolerance: from synthesis to regulation. Frontiers in Plant Science, 6:827. DOI: 10.3389/fpls.2015.00827.

LIU, K., FU, H., BEI, Q., LUAN, S. 2000. Inward potassium channel in guard cells as a target for polyamine regulation of stomatal movements. Plant Physiology, 24, 1315-1326. DOI: 10.1104/pp.124.3.1315.

LIU, T., DOBASHI, H., KIM, D. W., SAGOR, G. H. M., NIITSU, M. BERBERICH, T., KUSANO, T. 2014. Arabidopsis mutant plants with diverse defects in polyamine metabolism show unequal sensitivity to exogenous cadaverine probably based on their spermine content. Physiology and Molecular Biology of Plants, 20, 151-159. https://doi.org/10.1007/s12298-014-0227-5.

MA, Y., DAI, X., XU, Y., LUO, W., ZHENG, X., ZENG, D. et al. 2015. COLD1 confers chilling tolerance in rice. Cell, 160, 1209-1221. DOI 10.1016/j.cell.2015.01.046.

MAGNES , C., FAULAND A., GANDER E., NARATH S., RATZER M., EISENBERG T., MADEO F., PIEBER T., SINNER F. 2014. Polyamines in biological samples: Rapid and robust quantification by solid-phase extraction online-coupled to liquid chromatography-tandem mass spectrometry. Journal of Chromatography A $1331(100)$

44

https://doi.org/10.1016/j.chroma.2013.12.061.

MELONI, D., GULOTTA, M., MARTÍNEZ, C. 2008. Salinity tolerance in Schinopsis quebracho colorado: Seed germination, growth, ion relations and metabolic responses. Journal of Arid Environments, 72, 1785-1792. https://doi.org/10.1016/j.jaridenv.2008.05.003.

NAKASHIMA, K., ITO, Y., YAMAGUCHI-SHINOZAKI, K. 2009 Transcriptional regulatory networks in response to abiotic stresses in Arabidopsis and grasses. Plant Physiology, 149, 88-95. DOI: 10.1104/pp.108.129791.

NAMBEESAN, S., ABUQAMAR, S., LALUK, K., MATTOO, A. K. MICKELBART, M. V., FERRUZZI, M. G., MENGISTE, T., HANDA, A. K.
2012. Polyamines attenuate ethylene-mediated defense responses to abrogate resistance to Botrytiscinerea in Tomato. Plant Physiology, 158(2), 1034-1045. https://doi.org/10.1104/pp.111.188698.

NASR, S. M. H., PARSAKHOO, A., SKANDARI, S., GOJANI, H. J., SAVADKOOHI, S. K. 2012. Investigation of salinity tolerance in Dodonaea viscosa L. Journal of Applied Biological Sciences, 6:31-36.

NIEMI, K., HÄGGMAN, H., SARJALA, T. 2002. Effects of exogenous diamines on the interaction between ectomycorrhizal fungi and adventitious root formation in Scots pine in vitro. Tree Physioogy, 22, 373-381. DOI 10.1093/treephys/22.6.373.

PIQUERAS, A., CORTINA, M., SERNA, M. D., CASAS, J. L. 2002 Polyamines and hyperhydricity in micropropagated carnation plants. Plant Science, 162, 671-678. https://doi.org/10.1016/S0168-9452(02)00007-9.

PORTA, C., LÓPEZ-ACEVEDO, M., ROQUERO, C. 1999. Edafología para la Agricultura y el Medio Ambiente. Mundi-Prensa, Madrid.

POTTOSIN, I., VELARDE-BUENDIA, A.M., BOSE, J., ZEPEDA-JAZO, I. SHABALA, S., DOBROVINSKAYA, O. 2014. Cross-talk between reactive oxygen species and polyamines in regulation of ion transport across the plasma membrane: implications for plant adaptive responses. Journal of Experimental Botany, 65, 1271-1283. https://doi.org/10.1093/jxb/ert423.

PRAZERES, A. R., CARVALHO, F.․, RIVAS, J.., PATANITA, M., DÔRES, J. 2013. Growth and development of tomato plants Lycopersicon Esculentum Mill under different saline conditions by fertirrigation with pretreated cheese whey wastewater. Water Science and Technology, 67(9):2033-41. DOI 10.2166/wst.2013.085.

REDMAN, J. C., HAAS, B. J. TANIMOTO, G., TOWN, C. D. 2004 Development and evaluation of an Arabidopsis whole genome Affymetrix probe array. The Plant Journal, 38, 545-561. DOI:10.1111/j.1365-313X.2004.02061.x. RÍOS-GÓMEZ, R., SALAS-GARCÍA, C. E., MONROY-ATA, A., SOLANO, E 2010. Salinity effect on Prosopis laevigata seedlings. Terra Latinoamericana 28:99-107.

SAHA, J., BRAUER, E.K., SENGUPTA, A., POPESCU, S.C., GUPTA, K. GUPTA, B. 2015. Polyamines as redox homeostasis regulators during salt stress in plants. Frontiers in Environmental Science, 3, 21. DOI 10.3389/fenvs.2015.00021.

SHALABY, A. R. 2000. Changes in biogenic amines in mature and germinating legume seeds and their behavior during cooking. Food/Nahrung, 44(1), 23-27. DOI: 10.1002/(SICI)1521-3803(20000101)44:1<23::AID-FOOD23>3.0.CO;2-B SHEN, H. J., GALSTON, A. W. 1985. Correlations between polyamine ratios and growth patterns in seedling roots. Plant Growth Regulation, 3, 353-363. https://doi.org/10.1007/BF00117592.

SHI, H., YE, T., CHAN, Z. 2013. Comparative proteomic and physiological analyses reveal the protective effect of exogenous polyamines in the Bermudagrass (Cynodon dactylon) response to salt and drought stresses. Journal of Proteome Research, 12, 4951-4964. DOI: 10.1021/pr400479k.

SIMON-SARKADI, L., LUDIDI, N., KOCSY, G. 2014. Modification of cadaverine content by NO in salt-stressed maize. Plant Signalling and Behaviour, 9:e27598. DOI: $10.4161 / p s b .27598$.

STRZELCZYK, E., KAMPER, M., LI, C. 1994. Cytocinin-like-substances and ethylene production by Azospirillum in media with different carbon sources. Microbiological Research, 149:55-60. https://doi.org/10.1016/S0944 5013(11)80136-9.

TAKAHASHI T., TONG W. 2015. Regulation and Diversity of Polyamine Biosynthesis in Plants. In: Kusano T., Suzuki H. (eds). Polyamines. Springer Tokyo. https://doi.org/10.1007/978-4-431-55212-3_3.

TANOU, G., ZIOGAS, V., BELGHAZI, M., CHRISTOU, A., FILIPPOU, P., JOB, D. 2014. Polyamines reprogram oxidative and nitrosative status and the proteome of citrus plants exposed to salinity stress. Plant, Cell \& Environment, 37, 864-885. https://doi.org/10.1111/pce.12204.

TIBURCIO, A. F., ALTABELlA, T., BITRIAN, M., ALCAZAR, R. 2014. The roles of polyamines during the lifespan of plants: from development to stress. Planta, 240(1): 1-18. DOI: 10.1007/s00425-014-2055-9.

TOMAR, P. C., LAKRA, N., MISHRA, S. N. 2013. Cadaverine: A Lysine catabolite involved in Plant growth and development. Plant Signalling and Behaviour, 8(10), e25850. DOI: 10.4161/psb.25850.

TOMAR, P. C., MISHRA, S. N., RAJPAL, C. (2017). Effect of cadaverine on protein profiling of brassica juncea (rh-30) seedlings under multiple stress Indian Journal of Advanced Information Science and Technology, 6(3), 49-62. DOI:10.15693/ijaist/2017.v6i3.49-62.

VASSILEVA, V., IGNATOV, G. 2002. Relationship between bacteroid polyhydroxybutyrate accumulation and nodule functioning in the Galega orientalis Rhizobium galegae symbiosis under diamine treatment. Physiologia Plantarum, 114(1), 27-32. DOI: 10.1046/j.0031-9317.2001.1140105.x.

VELARDE, M., FELKER, P., DEGANO, C. 2003. Evaluation of Argentine and Peruvian Prosopis germplasm for growth at seawater salinities. Journal of Arid Environments, 55:515-531. https://doi.org/10.1016/S0140-1963(02)00280-X. WALTER, D. 2003. Resistance to plant pathogens: possible roles for free polyamines and polyamine catabolism. New Phytologist, 159: 109-115. https://doi.org/10.1046/j.1469-8137.2003.00802.x 
WITZEL, K., WEIDNER, A., SURABHI, G.K., BÖRNER, A., MOCK, H.P. 2009. Salt stress-induced alterations in the root proteome of barley genotypes with contrasting response towards salinity. Journal of Experimental Botany, 60, 3545-3557. https://doi.org/10.1093/jxb/erp198.

YANG, J. C., ZHANG, J. H., LIU, K., WANG, Z. Q., LIU, L. J. 2007. Involvement of polyamines in the drought resistance of rice. Journal of Experimental Botany, 58, 1545-1555. https://doi.org/10.1093/jxb/erm032.

YUAN, Y., ZHONG, M., SHU, S., DU, N., SUN, J., GUO, S. 2016. Proteomic and physiological analyses reveal putrescine response in roots of cucumber stressed by $\mathrm{NaCl}$. Frontiers in Plant Science, 7, 1035. https://doi.org/10.3389/fpls.2016.01035.

ZELLER, G., HENZ, S. R., WIDMER, C. K., SACHSENBERG, T., RATSCH, G., WEIGEL, D., LAUBINGER, S. 2009. Stress-induced changes in the Arabidopsis thaliana transcriptome analyzed using whole-genome tiling arrays. The Plant Journal, 58, 1068-1082. DOI: 10.1111/j.1365-313X.2009.03835.X.

ZRIBI, L., FATMA, G., FATMA, R., SALWA, R., HASSAN, N., NEJIB, R. M. 2009. Application of chlorophyll fluorescence for the diagnosis of salt stress in tomato (Solanum lycopersicum, variety Rio Grande). Scientia Horticulturae, 120, 367-372. https://doi.org/10.1016/j.scienta.2008.11.025. 